\title{
AS MARCAS DE(INTER)SUBJETIVIDADE NAS TIRAS DE ANDRÉ DAHMER: UMA ANÁLISE ENUNCIATIVA
}

\author{
(INTER)SUBJECTIVITY MARKS IN ANDRÉ DAHMER"S COMICS: AN \\ ENUNCIATIVE ANALYSIS
}

Lucy Raiane Peres Farias ${ }^{137}$

Beatriz Gama Rodrigues ${ }^{138}$

RESUMO: Dos estudos postulados por Benveniste (1956) compreendemos que desde que nos declaramos locutores, nos apropriando da língua para enunciar, automaticamente implantamos o outro diante de nós, em maior ou menor grau de presença. Este artigo objetiva analisar tirinhas do autor André Dahmer na perspectiva do sujeito e intersubjetividade estudada por Benveniste (1956), explicando de que maneira se dá essa intersubjetividade, explicando os efeitos de sentido que săo construídos a partir das marcas de sujeito encontradas. Para tanto, as categorias utilizadas serăo, principalmente, as noçōes de pessoa e náo pessoa, de Benveniste (1956), operaçóes de localizaçăo, de Culioli (1982, apud CAMPOS, 1994, 1997) e modalidades, segundo Neves (2012). Os resultados obtidos a partir da análise mostraram a ocorrência de algumas marcas mais frequentes que outras, e pudemos perceber que a construçăo de sentidos de humor e crítica está imbricada às escolhas dessas categorias e marcas nos enunciados, marcas essas importantes para a relaçâo de (inter)subjetividade na perspectiva Culioliana.

Palavras-chave: Enunciaçấo; Quadrinhos; (Inter)subjetividade.

ABSTRACT: From the researches postulated by Benveniste (1956) we understand that since we declare ourselves speakers, appropriating the language to speak, we automatically implant the other in front of us, in a minor or major degree of presence. This article aims at analyzing comics from André Dahmer from the subject"s point of view and intersubjectivity postulated by Benveniste (1956), explaining in which ways this intersubjectivity happens, explaining the effects built from the subject marks found. In: order to do that, the categories used will be, mainly, thenotion of person and non-person, from Benveniste (1956), localization operations, from Culioli (1982, apud CAMPOS, 1994, 1997) and modalities, according to Neves (2012). The results from the analysis showed the occurency of some marks, wich were more frequent than others, and we could perceive that the construction of humour and critical meanings is related to the choices of these categories and marks in the speaking, marks which are important to the relation of (inter)subjectivity in Culioli"s perspective.

Keywords: Enunciation; Comics; (Inter)subjectivity.

137 Mestranda em Letras pelo Programa de Pós-graduaçăo em Estudos da Linguagem, Universidade Federal do Piauí (UFPI).E-mail: lucyperes@gmail.com

138 Professora da Universidade Federal do Piauí (UFPI). Doutora em Linguística Aplicada e Estudos da Linguagem pela PUC-SP. E-mail: beatriz@ufpi.edu.br 


\section{INTRODUÇÃO}

O presente trabalho consiste em análises feitas em tirinhas diversas do autor André Dahmer, sob a luz de alguns postulados e teorias enunciativas. Pretendemos, a partir da compreensāo do sentido no e pelo enunciado, identificar marcas no corpus selecionado que indicam a (inter)subjetividade, e, a partir da identificaçăo dessas marcas, explicar que efeitos de sentido foram obtidos em cada situaçăo enunciativa, em cada tirinha analisada.

Partiremos dos postulados de Benveniste (1956), o qual nâo construiu, em seus trabalhos, uma teoria, com operaçóes ou detalhamentos, mas contribuiu no sentido de trazer à tona a discussăo sobre o sujeito que se apropria da língua para se fazer eu. Para o autor, construímos o sentido do que dizemos na situaçăo em que dizemos. Portanto, se enunciar é um ato individual de colocar em funcionamento a língua, entăo o sentido139 se faz apenas no enunciado e pelo enunciado, e é a partir daí que se iniciam as teorias enunciativas.

Neste artigo buscamos discutir três aportes teóricos, os identificando dentro do corpus. Săo eles a noçâo, para os estudos da enunciaçăo, de subjetividade, ${ }^{140}$ a categoria que Benveniste (1956) discute de pessoa e năo pessoa e as marcas de modalidade, que se encontram dentro da noçăo de Operaçăo de Localizaçăo de Culioli (1982, apud CAMPOS, 1994; 1997). Para fins de pesquisa, e pelas limitaçôes metodológicas, selecionamos as categorias a trabalhar em um artigo; decerto que há inúmeras marcas existentes ou implícitas no enunciado, na situaçăo de enunciaçăo, que nos permitem enxergar a (inter)subjetividade ali estabelecida. As perguntas que motivam o presente artigo săo: a) De que maneira as marcas indicadoras de (inter)subjetividade das quais André Dahmer se utiliza criam efeitos de sentido de humor e crítica em suas tirinhas?; e b) Quais săo as marcas que o autor parece utilizar mais frequentemente e porque motivo isso ocorre? Basearemo-nos em Campos (1997), que discute noçóes de modalidade e localizaçăo, baseada em Culioli (1982) e sua Teoria das Operaçôes Predicativas Enunciativas; Neves (2012), com sua classificaçâo de modalidades e em Benveniste (1956), com postulados base para o entendimento da enunciaçấo como disciplina, suas categorias de pessoa e nâo-pessoa e a noçăo de subjetividade, a qual se destaca de todas as áreas alheias à enunciaçăo, à medida que toma o sujeito apropriador da língua para se fazer eu e apenas passa a ter consciência de si a partir do momento de sua enunciaçăo.

\section{AS NOÇÕES DE (INTER)SUBJETIVIDADE, A CATEGORIA DE PESSOA E NÃO-PESSOA E AS MARCAS DE MODALIDADE}

Benveniste (1956), em suas duas obras de maior conhecimento, intituladas "Problemas de Linguística Geral I" e "Problemas de Linguística Geral II", inicia, sem prever, um movimento na direçâo de uma nova disciplina, a Enunciaçấo. O autor nâo chegou a desenvolver uma teoria da enunciaçăo, porém, algumas categorizaçôes

139 Campos (1994, 1997) e Culioli (1982) utilizam o termo "construçăo de significaçăo", e, doravante, nâo faremos distinçóes entre este e a noçâo de sentido.

140 E, portanto, para Culioli (1982), de intersubjetividade, já que ambas andam sempre juntas. Separamos as duas noçóes para fins exclusivamente didáticos. 
surgiram entre outros estudiosos e leitores de sua obra Um dessas categorizaçóes foi a noçăo de pessoa e nâo pessoa, a qual nos servirá, neste artigo, de fundamentaçâo teórica para as análises propostas. Antes disso, porém, precisamos compreender o que para a disciplina de Enunciaçăo é a linguagem e como funcionam alguns dos processos envolvidos no fenômeno da comunicaçăo humana.

Benveniste explica que "é na linguagem e pela linguagem que o homem se constitui como sujeito; porque só a linguagem fundamenta, em sua própria realidade (que é a do ser), o conceito de "ego"'". Assim, o autor estabelece a noçáo de subjetividade para a Enunciaçấo, que seria a capacidade que tem o locutor para se propor como "sujeito", nâo em suas particularidades sentimentais, mas sim em sua completude psíquica, que se faz consciente de si, ou, nas palavras do autor, "é "ego" que diz ego" (2005b, p. 286). Silva (2012) afirma:

a subjetividade remete à presença do sujeito enunciador nas suas produçóes, o qual está presente em todo e qualquer ato comunicativo, mesmo que em graus diferentes, já que se tem enunciados bem mais subjetivamente marcados do que outros (SILVA, 2012, p. 66).

Portanto, năo podemos negar a existência dessas marcas de subjetividade, seja ela em qual grau se explicite no momento da enunciaçâo. Já a enunciaçăo, para Benveniste (2006), é o "colocar em funcionamento a língua por um ato individual de utilizaçấo" (p. 82) A partir daí inicia-se a noçăo do status de pessoa e o sujeito passa a ser aquele que se apropria da língua para dizer o que diz, num ato único e novo a cada vez.

Juntamente à noçăo de sujeito ou de eu estabelecida, vem a noçăo de tu, a alteridade, que também constituirá a categoria de pessoa, visto que, na perspectiva de Benveniste (1956) é nas noçôes de eu e tu que se encontra o diálogo, implicando reciprocidade, ou seja, que eu me torne tu no momento em que o outro se apropria da língua, sendo entăo o eu. Nenhum dos termos existe sem o outro, e assim o autor questiona se a linguagem seria mesmo linguagem sem essa propriedade de expressâo da subjetividade. Essas formas linguísticas que indicam a pessoa, ou seja, que a exprimem, eu e tu, năo se omitem em nenhuma das línguas que surgiram ou existem no mundo, seja em qual tempo for. Os ditos "pronomes pessoais" jamais faltam nessas línguas, daí que Benveniste exprime que "uma língua sem expressăo da pessoa é inconcebível" (1956, p. 287).

Devemos lembrar, também, que essa referência de eu e tu traz uma série de "indicadores" consigo, tais quais, outros pronomes, advérbios ou locuçōes adverbiais, entre outros. É o caso dos demonstrativos, este, essa etc. que se relacionam com o eu ou o tu. Advérbios como agora e aqui, e outros termos como hoje, ontem, segundo Benveniste (2005a), também associam-se às pessoas, no caso dos citados, ao eu, como instâncias espaciais ou temporais. Dessa forma, Benveniste (2005a) explica que é "fundamental [...] que essas formas "pronominais" năo remetam à "realidade" nem a posiçôes "objetivas" [...], mas à enunciaçâo, cada vez única [...] e reflitam assim o seu próprio emprego" (p. 280). Assim, os pronomes eu e tu devem estar sempre ligados em exercício da linguagem, bem como os dêiticos indicados para tempo e espaço.

Podemos entâo, em qualquer língua, identificar a pessoa em qualquer situaçâo de enunciaçăo, em grau maior ou menor, bem como a intersubjetividade, seja o co-enunciador o próprio enunciador ou outro. Para Silva (2012), quando nos utilizamos da 
forma verbal, podemos remeter a aspectos intersubjetivos a partir do momento que as palavras "sáo mobilizadas para serem utilizadas com vistas a provocar uma mudança de conduta do co-enunciador" (SILVA, 2012, p. 86)

Segundo Benveniste (2006), o locutor dispōe de uma série de funçōes para influenciar de alguma maneira o comportamento do alocutário desde o momento em que se apropria da língua. Um desses aparelhos é a modalidade, uma forma de manifestaçâo do enunciador no enunciado. Entretanto, Benveniste (2006) năo explora a noçăo de modalidades, ao que recorremos a outros autores e pesquisadores posteriores (também leitores de Benveniste), os quais tentam discutir a modalidade mais amplamente.

Antes de compreendermos modalidades, porém, é preciso entender a Teoria de Operaçôes Predicativas e Enunciativas (TOPE) de Culioli (1982, apud PAVEAU). Essa teoria contribui para que compreendamos, entre outros conceitos e fenômenos, o da intersubjetividade, quando consideramos a operaçăo de localizaçăo, a qual utilizaremos em nossas análises. Se para Culioli (1982, apud CAMPOS, 1994) “Enunciar é construir determinaçăo", essa determinaçáo, explica Campos (1994), pode se estabelecer da seguinte forma: "um termo ganha determinaçăo ao ser localizado em relaçâo a um segundo termo, o termo localizador, que é mais determinado que o primeiro" (p. 142). Paveau (2006) explica: quando dizemos, por exemplo, "O livro está sobre a mesa", o livro é localizado em relaçâo à mesa, esta última sendo denominada localizador. Essa operaçâo é executada por todo enunciador e coenunciador em seus enunciados (visto que para Culioli todo enunciador é também seu próprio coenunciador), e dependendo de como é executada, como veremos posteriormente, pode causar diferentes efeitos de sentido, incluindo o de humor. As modalidades estăo inseridas no grupo das operaçóes de localizaçấo, sâo um dos tipos de localizaçấo.

Campos (1994; 1997) é uma das autoras que desenvolveram as noçôes e funcionamento das modalidades. Segundo a autora, "enunciar é construir determinaçâo" (CAMPOS, 1997, p. 151), ou seja, partimos de uma estrutura abstrata (que a autora chama de relaçăo predicativa) e a partir dela promovemos uma série de operaçôes de localizaçăo (com maior ou menor grau de determinaçăo) que irâo determiná-la. A uma dessas operaçôes, Campos (1997) denomina de modalizaçăo, ou operaçôes modais, que para ela podem ser de opiniâo ou de saber. Dessa maneira, a modalizaçâo é importante indicador da presença do sujeito e principalmente da intersubjetividade, já que pode influenciar o comportamento do coenunciador.

Neves (2012) divide, em seu trabalho, as modalidades em três tipos: epistêmicas, deônticas e apreciativas, cada qual indicando marcadores linguísticos da presença do sujeito e da intersubjetividade, seja em qual enunciado elas se executem. A modalidade epistêmica caracteriza "valores de reforço de validaçăo enunciativa e a interrogaçâo retórica" (NEVES, 2012, p. 82), ou seja, demonstra presença do enunciador bem como suas escolhas categóricas para validar seu próprio enunciado. A pergunta retórica aí se encaixa por ser entendida, em estudos compartilhados, como uma asserçâo, já que contém sua própria resposta. Dessa forma, funciona náo como uma pergunta a qual suscita uma resposta, mas sim como um marcador de alto grau persuasivo, considerando o coenunciador, e mostrando, assim, alto valor de intersubjetividade quando aparece no enunciado.

A modalidade deôntica indica ainda maior grau de intersubjetividade, já que corresponde a uma relaçăo entre enunciador e o outro, na medida em que, a partir de 
realizaçóes linguísticas, esse enunciador pretende agir sobre o coenunciador, "pressionando-o ou autorizando-o, a realizar uma determinada atividade" (NEVES, 2012, p. 86). Exemplos dessa modalidade sâo os imperativos e expressōes como "é necessário", verbos ter de/que, poder, dever, entre outros. O terceiro tipo de modalidade citado pela autora é a apreciativa, que se caracteriza por ter caráter avaliativo atribuído ao conteúdo do enunciado. Esse caráter avaliativo será marcado justamente pelo enunciador, mostrando assim sua subjetividade e tentativa de influenciar o outro, seu co-enunciador. Entendemos também, sob essa perspectiva, a intersubjetividade nesse tipo de modalidade marcada no enunciado.

\section{METODOLOGIA}

O corpus analisado consiste em tiras variadas de André Dahmer, quadrinhista conhecido por publicaçōes no jornal Folha de Săo Paulo e O Globo. O autor nâo utiliza de tempo cronológico em suas tirinhas, sendo cada uma independente da próxima ou anterior. Também desenha tiras com conteúdo variado, alternando geralmente política, religiâo, figuras públicas, e situaçôes do cotidiano, numa abordagem bastante crítica e por vezes politicamente incorreta. Seu trabalho tem conteúdo ácido, reflexivo e humorístico.

Buscaremos, durante as análises propostas às tirinhas, identificar as marcas de sujeito e marcas que coloquem em evidência a intersubjetividade nos diálogos travados, focando também em explicar como e porque ocorreram as escolhas pelos sujeitos para a produçăo de efeitos de sentido, principalmente os de humor e crítica, mais utilizados pelo autor. Para isso, utilizaremos dos aportes teóricos explicitados anteriormente, como as marcas de modalidade, a utilizaçăo dos pronomes pessoais e dêiticos, fazendo também uso de parte dos conceitos da Teoria de Operaçóes Predicativas e Enunciativas de Culioli.

\section{ANÁLISE ENUNCIATIVA DAS TIRINHAS}

Figura 1 - Quadrinhos dos Anos 10

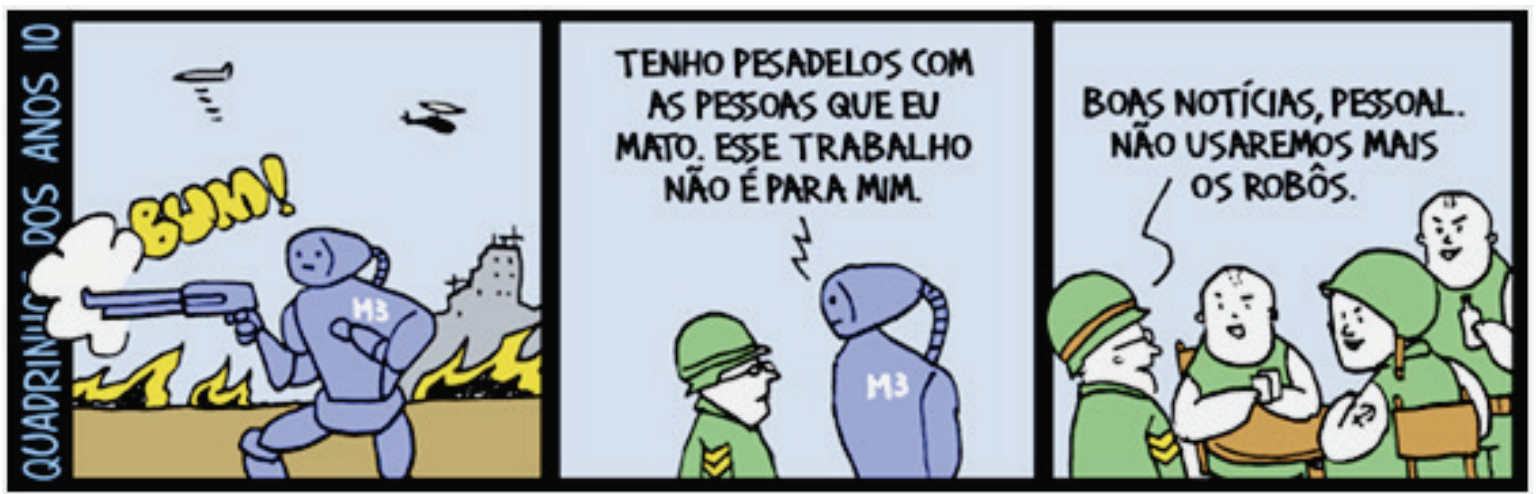

Fonte: Malvados da Depressão.

Disponível em: <www.malvados.com.br> Acesso em: 25 out. 2015. 
Na tirinha acima ( figura 1) há um robô apropriando-se da língua para se fazer sujeito, no momento de sua enunciaçăo. O estabelecimento da subjetividade em um robô, por sua apropriaçăo da língua como eu (ao utilizar o pronome "eu" em "as pessoas que eu mato", bem como características tipicamente humanas por ele enunciadas (ter pesadelos, trabalhar) produz sentido para a compreensâo da crítica na tirinha. O robô, dessa maneira, "humaniza-se" a ponto de desfazer-se do "trabalho" que lhe foi atribuído: "Esse trabalho năo é para mim". A escolha do pronome demonstrativo "esse" também indica o distanciamento do robô com o trabalho que fazia, indicando que o trabalho é pertencente ao outro, ao tu.

Já no enunciado "Boas notícias, pessoal. Năo usaremos mais os robôs.", encontramos marca de modalidade apreciativa. Quando o enunciador indica "boas notícias", ele marca a si próprio no enunciado, mostrando caráter avaliativo, ou seja, ele pensa que as notícias a serem dadas seráo boas, temos marcada a subjetividade. Podemos perceber melhor a modalidade apreciativa quando substituímos o enunciado por um equivalente "Săo boas as notícias de que náo usaremos mais os robôs" ou "Năo usarmos os robôs sâo boas notícias". Há, entâo uma relaçâo predicativa entre "Boas notícias, pessoal" e "Năo usaremos mais os robôs". Mais além, podemos perceber forte intersubjetividade quando o enunciador se dirige ao "pessoal", ao grupo de soldados, ele julga serem boas as notícias para todos ali presentes.

Săo justamente a identificaçăo de subjetividade em um ser inanimado e a quebra de expectativa quanto à escolha das marcas, como no caso de "boas notícias", que promovem os efeitos de sentido do humor e da crítica. Essa última pode ser validada quando observamos que na situaçăo da enunciaçăo (contexto de guerra) o robô, tecnicamente um "ser" criado pela tecnologia, uma máquina sem sentimentos, afirmar ter pesadelos e consciência originalmente humanos, enquanto que, num segundo momento, o general, na situaçáo enunciativa em que se encontra, e sendo, ele sim, humano, entende que năo utilizar os robôs configura "boas notícias". Dessa forma a crítica passada é a de que o homem, ser essencialmente subjetivo, tem cada vez mais se tornado "máquina" e perdido seu status de sujeito consciente e com remorso pela guerra, enquanto que as próprias máquinas "parecem" ser mais humanas que os mesmos.

Na tirinha a seguir ( figura 2), podemos identificar um diálogo entre os dois personagens sobre Deus:

Figura 2 -Deus em caixinha
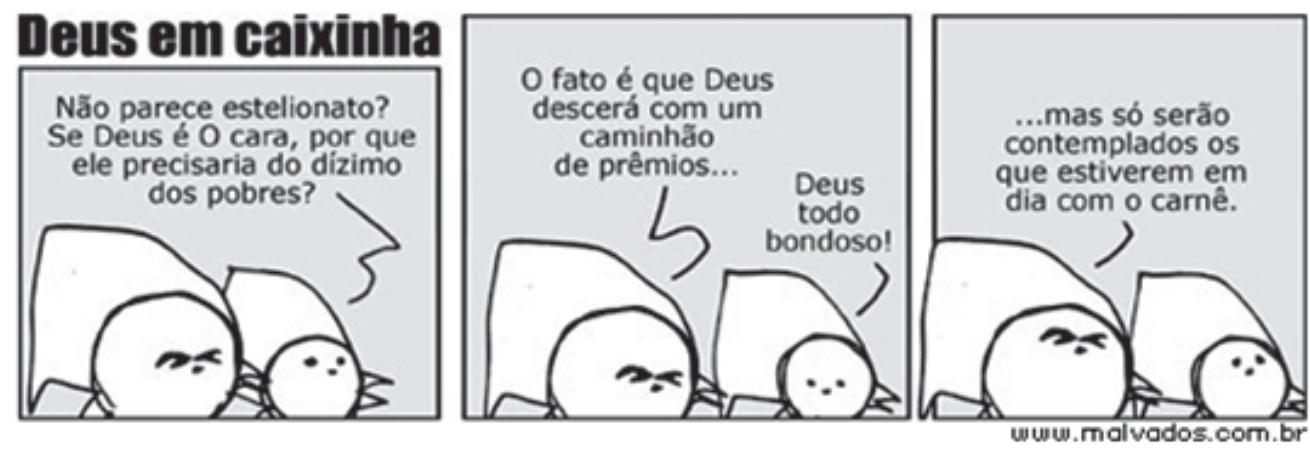

Fonte: Deus em Caixinha.

Disponível em: <www.malvados.com.br> Acesso em: 25 out. 2015. 
O primeiro enunciado "Năo parece estelionato? Se Deus é O cara, por que ele precisaria do dízimo dos pobres?" traz duas interrogaçōes. A primeira, podemos perceber, é um recurso de modalidade apreciativa, a valer-se da escolha lexical "estelionato", de caráter avaliativo por parte do enunciador. É também uma pergunta retórica, na medida em que o enunciador tenta convencer, com marca que indica seu posicionamento, como observamos na interrogativa seguinte, que configura, na situaçăo enunciativa, muito mais uma argumentaçâo do que um questionamento que suscita resposta do coenunciador. Assim, o enunciador nâo busca uma validaçăo de sua pergunta no co -enunciador, mas sim, convencê-lo de seu próprio posicionamento quanto ao assunto comentado. Também, a intersubjetividade é delineada quando, partindo-se de "Se Deus é O cara...", o enunciador enuncia nâo sua própria noçăo, mas sim, uma noçăo já validada coletivamente, a de que Deus é muito importante, bondoso, e piedoso, indicado nas marcas mais atuais "O cara".

Quando o coenunciador enuncia "O fato é que Deus descerá com um caminhăo de prêmios...", ele indica um grau de certeza em "O fato é que", que podemos categorizar como uma modalidade epistêmica, já que valida totalmente a relaçăo predicativa. Para visualizarmos melhor, podemos substituir por "Sem dúvida que", "Certamente". Essa escolha de marcador de modalidade pode sugerir a fé que os fiéis têm por seu deus, reproduzindo assim, um efeito de sentido. Assim, na resposta do coenunciador - "Deus todo bondoso!" - confirmamos o efeito de sentido de fé, e dos rituais religiosos de repetiçâo de frases em louvor a Deus. O coenunciador julga o deus um "Deus todo bondoso!" por descer com um caminhăo de prêmios, como citado no enunciado anterior.

Em seguida o coenunciador continua “... mas só serăo contemplados os que estiverem em dia com o carnê". O elemento "mas" liga-se diretamente ao enunciado "Deus todo bondoso!", numa relaçăo de condiçăo. Ou seja, existe uma condiçăo, um contraste, pois Deus năo é tâo bondoso, já que o elemento "mas", na situaçâo de enunciaçăo, opóese ao enunciado anterior.

Quando consideramos "só serăo contemplados os que estiverem em dia com o carnê", percebemos relaçăo predicativa dentro do próprio enunciado. Há uma condiçăo para a contemplaçăo com prêmios para os fiéis, a qual é "estar em dia com o carnê", há, assim, a localizaçăo do elemento "ser contemplado" em relaçáo a outro elemento, o localizador "estar em dia com o carnê".

É possível, também, identificar modalidade deôntica no enunciado, embora bastante implícita, pois năo é marcada claramente, como seria, por exemplo, em "é necessário estar com o carnê em dias para ser contemplado". A comicidade da tirinha se dá pela interaçăo dos sujeitos (intersubjetividade) na situaçăo enunciativa que indica discurso religioso, comparando-o à atual venda de carnês para obtençăo de prêmios, ou seja, comparando a religiáo na atualidade com o capitalismo, com a venda de milagres e glórias.

Na tirinha abaixo ( figura 3), encontramos o efeito de sentido de humor, com a quebra da expectativa do leitor, por conta também das marcas de intersubjetividade, através da operaçăo de localizaçăo, como explicado a seguir: 
Figura 3 - Malvados da depressão
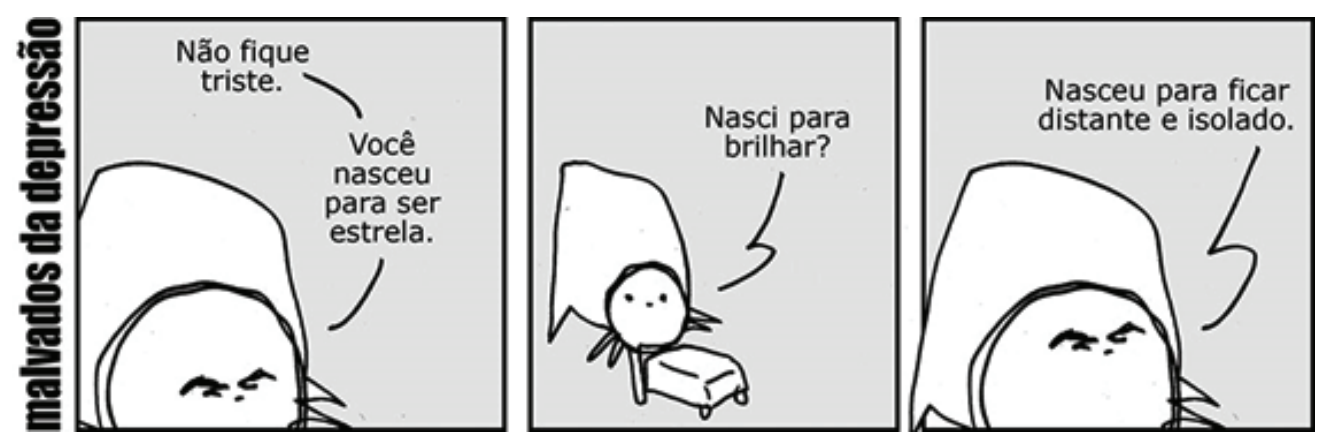

Fonte: Malvados da Depressão.

Disponível em: <www.malvados.com.br> Acesso em: 25 out. 2015.

O imperativo na negativa "Năo fique triste" indica modalidade deôntica, marcas as quais correspondem a uma forte noçâo de intersubjetividade, já que a modalidade em questâo constrói uma relaçâo entre o enunciador e seu coenunciador. Dessa forma, o enunciador age sobre o coenunciador, influenciando-o, na situaçăo enunciativa acima, a realizar uma atividade, a qual seria mudar de comportamento. Em seguida, o enunciado "Você nasceu para ser estrela" como argumentaçăo aparentemente em favor do anterior (veremos em seguida que isso năo se valida), numa relaçăo predicativa implícita, a marca "porque" năo se mostra, mesmo assim sabe-se que há relaçâo causal.

Em seguida o coenunciador enuncia "Nasci para brilhar?", em busca de validaçăo por parte do outro. A comparaçăo de "brilhar" com "estrela" marca a operaçấo de localizaçāo, ou seja, "brilhar" está localizado em relaçăo à "estrela", que é o localizador, sendo essa comparaçâo a mais comumente e frequentemente encontrada nas situaçôes enunciativas. Entretanto, o humor da tirinha se dá justamente pela quebra da operaçâo de localizaçáo comumente recorrente, que é "estrela" e "brilhar", ou seja, há a quebra de expectativa do leitor, bem como dos coenunciadores (um ao enunciar e o outro ao interagir). O coenunciador refuta, ou seja, náo valida, dessa forma, o questionamento do enunciador, ao responder "Nasceu para ficar distante e isolado". Dessa maneira, a operaçăo de localizaçăo se dá entre "estrela" e "distante e isolada do planeta", produzindo o efeito de sentido de humor com a situaçáo enunciativa que foi mostrada.

Em seguida, na tirinha da figura 4, analisamos de que maneira a quebra de expectativa e o efeito de humor se constroem dentro da intersubjetividade denominada pelo autor:

Figura 4 -Malvados

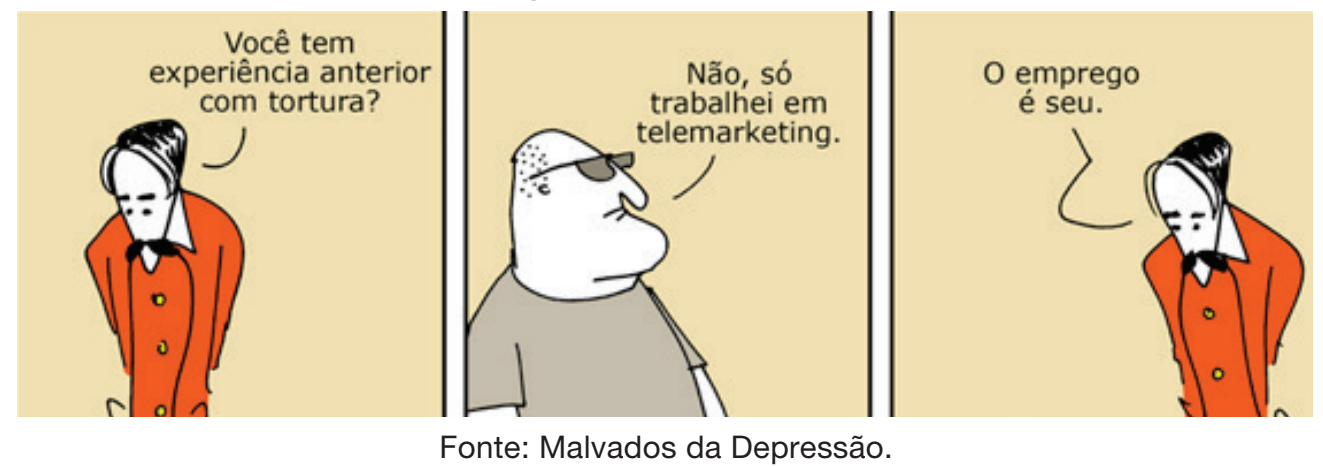

Disponível em: <www.malvados.com.br> Acesso em: 25 out. 2015. 
$\mathrm{Na}$ figura 4, a intersubjetividade se faz presente e bem marcada na interrogativa inicial, por meio da qual o enunciador dá ao tu, o qual ele denomina "você", o poder de validaçáo da pergunta. A situaçáo de enunciaçáo parece, dessa forma, a partir das marcas no enunciado inicial, uma situaçăo de entrevista ou questionamento para preenchimento de vagas em um emprego.

O coenunciador invalida a interrogativa inicial, já de início, com o elemento "náo" e em seguida elabora seu enunciado com sua única experiência profissional anterior "só trabalhei em telemarketing", ou seja, "apenas trabalhei em telemarketing". Quando percebemos essas marcas em conjunto, entendemos que para o coenunciador o telemarketing nâo configura experiência com tortura. Entretanto, o sujeito inicial volta a enunciar "O emprego é seu", implicitamente implicando que ele próprio considera o "telemarketing" diretamente localizado em relaçăo à "tortura", o que, na situaçáo de enunciaçăo, produz o efeito de humor e crítica à ocupaçăo do profissional de telemarketing. Dessa maneira, o efeito de humor se dá em maior parte pela subjetividade de cada um dos enunciadores, pois suas operaçôes de localizaçăo diferiram em relaçáo aos dois elementos (para um deles essa localizaçâo se valida, e para o outro, năo), e dessa subjetividade na operaçấo de localizaçâo surge a quebra de expectativa do leitor no momento da leitura, inicialmente imagina-se que o leitor poderá concordar com o enunciador no segundo quadrinho, quando este diz que năo tem experiência com tortura, apenas trabalhou em telemarketing. Porém, posteriormente, no terceiro quadrinho, o leitor pode vir a ajustar, assim como o enunciador em "O emprego é seu", sua operaçăo de localizaçăo, entre "tortura" e "telemarketing". O efeito de humor paira entre o estabelecimento ou náo da operaçăo de localizaçấo entre "tortura" e "telemarketing". Já a intersubjetividade se faz no diálogo da figura 4 a partir da interrogativa e auxiliada pelas escolhas pronominais "seu", "você".

Na figura 5, em seguida, identificamos um diálogo também com efeito de humor no leitor, com marcas de intersubjetividade relativas ao tempo, à interrogativa e à localizaçăo:

Figura 5 - Malvados II
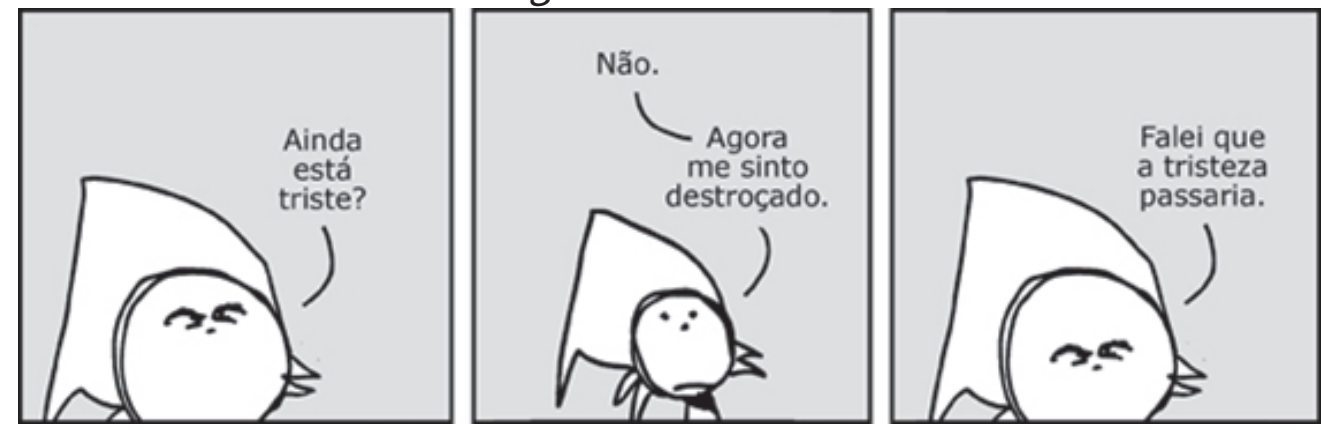

Fonte: Malvados da Depressão.

Disponível em: <www.malvados.com.br> Acesso em: 25 out. 2015.

Na figura 5, percebemos, no primeiro enunciado ("Ainda está triste?"), a relaçáo de intersubjetividade estabelecida pelo enunciador por meio do advérbio "ainda", o qual implica, necessariamente, um conhecimento anterior por parte desse enunciador, um estado que iniciou-se em um ponto anterior ao da enunciaçăo, sobre o qual o 
enunciador conhece e estabelece interrogativa, cabendo ao co-enunciador o poder de validar ou năo, na interaçáo com o outro, a questăo elaborada.

Em seguida, o coenunciador invalida a interrogativa por meio do elemento "năo", mais especificamente invalidando o elemento "triste", ao que o leitor imediatamente poderá esperar o oposto equivalente do elemento "triste", o qual viria a ser "feliz" ou, ao menos, "nâo triste". Entretanto, ao invés de "Năo, agora năo estou mais triste." ou "Năo. Agora estou feliz/melhor", o enunciador intensifica o elemento "triste" com seu enunciado "Nâo. Agora me sinto destroçado". Ou seja, para o enunciador, "destroçado" năo se localiza em relaçâo à "triste", razâo da escolha do marcador "náo", invalidando a tristeza, e corrigindo para o sentimento que ele sente no "agora". Assim, a subjetividade do enunciador ao escolher marcar o "năo", posteriormente fazendo com que esse "năo" năo invalide, mas sim, permita a intensificaçáo do sentimento, produzindo o efeito de quebra de expectativa no leitor, que, comumente, năo exclui o sentimento "triste" do localizador "destroçado", pelo contrário, quando alguém se sente destroçado, se sente também triste, em geral. Finalmente, no último quadrinho, o co-enunciador, em "Falei que a tristeza passaria", e compartilhando do mesmo ponto de vista do outro, indica a nâo localizaçăo do elemento "triste" em relaçâo à "destroçado". Por exemplo: "Falei que a tristeza passaria" pode ser compreendida na situaçăo enunciativa como "Você năo está mais triste, eu lhe falei que a tristeza passaria", ou seja, o coenunciador náo está mais triste, está destroçado. Essa quebra dupla e seguida de expectativa do leitor, através das escolhas de marcas por parte dos coenunciadores da tirinha, é que pode ser o desencadeador do efeito de humor, uma vez que comumente se considera o "năo" um elemento de invalidaçăo, quase que em todas as situaçôes de enunciaçăo, o que nâo ocorre completamente no caso explicitado acima.

\section{DISCUSSÃO SOBRE A ANÁLISE}

Através de análise cuidadosa dos dados de corpus selecionados, à luz da teoria enunciativa e de postulados inerentes à mesma, pudemos perceber uma parte do papel da subjetividade e intersubjetividade dentro da construçáo de sentido que o autor objetiva em seus trabalhos. Sendo a (inter)subjetividade indissociável da enunciaçâo no que tange à epistemologia da disciplina. Nâo foi difícil encontrarmos suas inúmeras marcas construídas e introduzidas nos enunciados produzidos. Entretanto, compreender, dentro do processo de enunciar e construir determinaçăo, e, portanto, significaçăo, de que maneira essas marcas de inter(subjetividade) constroem efeitos de sentido no e pelo enunciado parece-nos uma atividade um pouco mais complexa.

Procurando compreender de que maneira essas marcas de (inter)subjetividade foram imprescindíveis nas construçōes de sentidos humorísticos e críticos, atemo-nos a poucas categorias das muitas existentes e passíveis de análise, sabendo que a identificaçáo de todas seria demasiado extensa. Abaixo, na figura 6, apresentamos tabela com ocorrência de cada uma das marcas linguisticamente explicitadas nas tirinhas, pelo menos uma vez, para facilitar a visualizaçăo da quantidade de ocorrências. 
Tabela 1 - Tabela de ocorrência de marcas de (inter)subjetividade (2015)

\begin{tabular}{c|c|c|c|c|c} 
& figura 1 & figura 2 & figura 3 & figura 4 & figura 5 \\
\hline Pronomes & $\mathrm{x}$ & $\mathrm{x}$ & $\mathrm{x}$ & $\mathrm{x}$ & $\mathrm{x}$ \\
\hline Interrogativa & & $\mathrm{x}$ & $\mathrm{x}$ & $\mathrm{x}$ & $\mathrm{x}$ \\
\hline Localização & & $\mathrm{x}$ & & \\
\hline Modalidade & $\mathrm{x}$ & $\mathrm{x}$ & & \\
\hline Pessoa/ não-pessoa & $\mathrm{x}$ & $\mathrm{x}$ & $\mathrm{x}$ & & \\
\hline Outros & & & & $\mathrm{x}$ \\
\hline
\end{tabular}

Fonte: os autores.

A ocorrência dos pronomes nas tirinhas era esperada para a maior parte das tirinhas, por sua ocorrência em geral em situaçóes de enunciaçăo cotidianas, quando tratamos da língua portuguesa. Os chamados "pronomes pessoais" encontrados na gramática normativa sâo largamente utilizados em português em situaçôes comunicativas variadas. Entretanto, para esta categoria, podemos afirmar que em apenas uma delas (tirinha 1), a utilizaçăo dos pronomes (eu e mim) foi de grande relevância para a construçâo de sentido dentro da tirinha. É o caso do robô, que se humaniza ao utilizarse desses pronomes tipicamente subjetivos, trazendo para si a significaçăo de subjetividade exclusiva do ser humano. Para as tirinhas restantes, a utilizaçăo dos pronomes nâo configura grande parte na significaçâo de humor ou crítica, pois esses sentidos humorísticos ou críticos se fazem por meio de outras marcas acima identificadas, sozinhas ou combinadas. A presença pronominal também năo tem papel tăo relevante nas significaçôes, pois, em português, as terminaçôes verbais já trazem consigo a ideia pronominal: por exemplo, "Năo fique assim” já nos indica que há um tu, ou seja, há uma marca de alteridade indicada pelo verbo conjugado (fique), o qual, de acordo com a gramática prescritiva, indica consequentemente o pronome "você".

A marca interrogativa, também bastante frequente na tabela indicada na figura 6 , indica grande intersubjetividade, seja na intençấo do enunciador em suscitar no seu co-enunciador uma validaçấo de sua pergunta, seja como marca de modalidade, no objetivo do enunciador, em uma situaçấo de enunciaçăo, de convencer, influenciar o seu co-enunciador, como ocorre, por exemplo, na tirinha da figura 2. Nas tirinhas analisadas, as interrogaçôes utilizadas tiveram as duas funçôes, suscitar do co-enunciador uma validaçâo, ou mostrar marca de modalidade no sentido de convencê-lo; ambas as funçōes, portanto, indicam alto grau de intersubjetividade ao expor a relaçăo entre os sujeitos, entre o eu e o tu.

Seguindo ordem decrescente de ocorrência, as operaçōes de localizaçăo sobre as quais discorre Culioli (1982) aparecem em três das tirinhas analisadas, e indicam, também, alto grau de intersubjetividade. Isso porque mexem com o nível 1 de representaçăo indicado por Campos (1994), o nível das noçôes e operaçōes, ou seja, o nível das "representaçôes abstratas de natureza cognitiva, pré-lexicais e pré-enunciativas" (CAMPOS, 1994, p. 139). Dessa forma, essas noçōes săo construídas por cada sujeito em sua subjetividade, e, portanto, podem variar para cada um. Essas representaçóes abstratas săo também construídas no meio sociocultural, portanto coletivas e 
intersubjetivas. A partir das diferenças entre noçōes de diferentes sujeitos, é que as operaçóes de localizaçăo causam os efeitos de sentido pretendidos pelo autor, quando uma localizaçăo (ou náo localizaçáo) entre dois termos marcados é prevista pelo leitor, mas năo-validada posteriormente na tirinha, levando ao efeito de humor pela quebra de expectativa.

Em seguida, as modalidades apreciativas que săo marcadas nas tirinhas das figuras 1 e 2, constroem efeito de crítica, respectivamente aos humanos "desumanizados" e ao modo como a religiâo é tratada atualmente, indicando, dessa forma, a tentativa do autor, por meio da enunciaçáo de seus personagens, de argumentar e convencer o leitor de seu ponto de vista. A modalidade utilizada dessa forma, pelo autor, indica muito de sua própria subjetividade na enunciaçâo de seus personagens. Finalmente, a categoria de pessoa e năo pessoa, marcada na tirinha da figura 1, é relevante para a construçáo do sentido de crítica, pois joga diretamente com a subjetividade e a noçáo de sujeito de Benveniste (1956). O fato de ser um robô a se apropriar da língua, utilizando-se para isso do pronome "eu" e se fazendo "ego" dentro de sua enunciaçăo, ou seja, se fazendo sujeito, o personifica, o humaniza. Essa noçăo, juntamente com a modalidade apreciativa citada acima e utilizada na mesma tirinha, traz o efeito de crítica ao mostrar o robô como mais humano do que o próprio ser humano.

Na categoria "outros" da tabela da figura 6, contabilizamos três ocorrências de marcas nas enunciaçōes que foram relevantes para o estabelecimento da (inter)subjetividade, porém, năo puderam ser classificadas em nenhuma das outras categorias. Sáo eles, na figura 1, a utilizaçâo do substantivo "pessoal", na figura 2, a conjunçấo "mas" e na figura 5, o advérbio "ainda". Dentro de suas respectivas situaçōes enunciativas, essas marcas tiveram seus valores intersubjetivos na medida em que marcaram, no discurso, a interaçấo entre o eu e o outro.

\section{CONSIDERAÇÕES FINAIS}

Este artigo teve como objetivo analisar, sob um olhar das teorias enunciativas, tirinhas do autor André Dahmer, para tentar explicar de que maneira se marcam nas enunciaçōes os elementos que contribuem para a construçâo de significaçôes, ou seja, de sentidos, tanto de humor, como de crítica. Para isso nos utilizamos das noçôes de sujeito, subjetividade e categorias de pessoa e nâo pessoa, de Benveniste (1956), intersubjetividade e operaçôes de localizaçăo, de Culioli (1982, apud CAMPOS, 1994, 1997) e modalidades, segundo Neves (2012).

A partir da análise detalhada do corpus, pudemos investigar de que forma o autor constrói sentidos de humor, de crítica e, mais além, tenta convencer o leitor de suas próprias opiniōes, por meio dos enunciados de seus personagens. Considerando a amplitude das teorias enunciativas, buscamos contribuir para as análises enunciativas, aumentando o escopo de pesquisas na área, através da categorizaçăo de algumas marcas indicadoras de intersubjetividade, que, nas situaçôes enunciativas em que ocorreram, foram cruciais para a construçăo de significaçăo.

Nesse sentido, pretendemos frisar a importância de estudarmos a língua e, principalmente, o ato de apropriar-nos da língua, para determinar, como dizem os autores na área. De outra forma, sabemos que a língua é abordada em sala de aula, e situaçôes 
de ensino, de maneira estática e segmentada em categorias que pouco refletem sua forma e suas funçōes. Através dos estudos das teorias enunciativas é que nos permitimos o olhar para a língua de uma perspectiva subjetiva, e assim, dentro do enunciado e pelo enunciado é que se encontram construídas todas as significaçóes e sentidos pretendidos.

Os estudos sobre intersubjetividade e marcas enunciativas săo amplos e genéricos, e, portanto, necessitam de recortes para que análises mais detalhadas sejam feitas. Dessa forma recortamos algumas das categorias que julgamos importantes para o corpus selecionado, na construçâo de sentidos, compreendendo que muitas outras foram deixadas de lado. Para futuros estudos utilizando o corpus de tirinhas do autor (ou outros), o qual é bastante extenso, deixamos sugestóes de estudos com modalidades, tempo, pessoa e lugar, aspecto, entre outras categorias próprias da disciplina. 


\section{REFERÊNCIAS}

BENVENISTE, Émile. A natureza dos pronomes. In: Problemas de Linguística Geral I.. Campinas: Pontes, 2005a.

Da subjetividade na linguagem. In: 2005b. . O aparelho formal da enunciaçăo. In: 2006.

CAMPOS, M. H. C. Abordagem semântico-enunciativa de alguns problemas gramaticais. In: Máthesis 3, Universidade Católica Portuguesa, Faculdade de Letras, Viseu, 1994. pp. 137-150.

. Para uma distinçăo formal entre operaçóes de modalizaçăo: sobremodalizaçăo e remodalizaçăo.In: _. Tempo, aspecto e modalidade: estudos de linguística portuguesa. Portugal: Porto, 1997.

DAHMER, André. Malvados. Disponível em: <http://www.malvados.com.br.>. Acesso em: Jun. 2015.

NEVES, J. S. B. Marcadores da modalidade e do mediativo no Correio Braziliense e na Gazeta de Lisboa. In: Corre voz no jornalismo do início do século XIX: estudo semântico-enunciativo do Correio Braziliense e da Gazeta de Lisboa. Jundiaí: Paco, 2012.

PAVEAU, M; SARFATI, G. Teoria da Enunciaçâo e Polifonia: O. Ducrot. In: As grandes teorias da linguística: da gramática comparada à pragmática. Săo Carlos: Claraluz, 2006.

SILVA, M. M. O. Modalidades subjetivas e intersubjetivas nos perfis do Orkut: uma análise na perspectiva da teoria das operaçóes predicativas e enunciativas. Teresina, UFPI, 2012. Dissertaçăo (Mestrado em Linguística) - Programa de Pós-Graduaçăo em Letras, Estudos de Linguagem, Universidade Federal do Piauí, Teresina, 2012. 